\title{
Diet and cancer: assessing the risk
}

\author{
C. I. R. Gill* and I. R. Rowland \\ University of Ulster, Cromore Road, Coleraine, Co. Londonderry, BT52 ISA, UK
}

\begin{abstract}
Globally, colorectal cancer (CRC) is a leading cause of mortality from malignant disease. Case-control and cohort studies provide strong support for a role of diet in the aetiology of $\mathrm{CRC}$. However to establish causal relationships and to identify more precisely the dietary components involved, intervention studies in human subjects are required. Cancer is an impractical endpoint in terms of numbers, cost, study duration and ethical considerations. Consequently, intermediate biomarkers of the disease are required. This review aims to provide an overview of the intermediate endpoints available for the study of CRC, particularly non-invasive faecal biomarkers. Examples of their use in dietary intervention studies are given.
\end{abstract}

\section{Colorectal cancer: Biomarkers: Diet: Gut microflora}

\section{Cancer epidemiology}

Cancer is an important global public health problem. Annually $10 \cdot 1$ million new cancer cases are diagnosed with a further 6.2 million people losing their lives worldwide. This disease accounts for a quarter of all deaths in countries with a Westernised lifestyle (International Agency for Research on Cancer (IARC), 2000). Colorectal cancer (CRC) is the fourth most common cause of cancerrelated mortality in the world. Approximately 944000 new cases were diagnosed globally in 2000 and this accounts for $9.2 \%$ of all new cancer cases (IARC, 2000). Within Europe, North America, Australia and New Zealand, it is the second most common cancer after lung or breast (Boyle \& Langman, 2000). In 2000, 363000 new cases were reported in Europe. CRC affects $6 \%$ of men and women by the age of 75, in almost equal proportions. Pronounced differences appear to exist in 5-year survival following cancer diagnosis between the UK (30-35\%) and the USA (50-55\%; Sant et al. 1995). The reasons for such a discrepancy remain unclear, but are likely to be attributed to the progression at diagnosis or treatment delivery. Generally the incidence and mortality of the disease are increasing (Cummings et al. 1996; Boyle \& Langman, 2000). The Modena colorectal registry (Italy) reported a $12.2 \%$ increase in incident rates from 1985 to
1997 and other European studies have reported similar trends (Johansen et al. 1993; Kemppainen et al. 1997).

Globally, incidence rates show an approximate 20-fold variation, with the developed world suffering the highest rates and India one of the lowest (IARC, 2000). Even within countries the rates may vary, as in India where the Westernised Parsi population have a higher rate of CRC than the strictly vegetarian Janists (Indian Cancer Society, 1985). Such fluctuations are generally attributed to both genetic factors and environmental factors, especially diet. Migrant studies (Japan to USA, Eastern Europe to North America) give further support to the role of environmental factors in the aetiology of colorectal malignancies, with reported incidence rates of migrants and their descendants reaching those of the host country, sometimes within one generation (World Cancer Research Fund (WCRF), 1997). The highest rates of the disease are currently seen within Hawaiian Japanese men with an incidence of 53.5 per 100000 (IARC, 1997).

Evidence suggests that diet plays a significant role in the aetiology of CRC. Identifying conclusively which constituents (e.g. vegetables, meat, fibre, fat, micronutrients) exert an effect on risk has been more problematic however, due to inconsistent data (Potter, 1999). The 1997 WCRF report concluded that the evidence (mainly from case-control studies) for diets rich in vegetables protecting against CRC was convincing, but that the effect of fruits could

Abbreviations: APC, adenomatous polyposis coli; ATNC, apparent total NOC; CCPS, crypt cell proliferative state; CRC, colorectal cancer; DAG, diacylglycerol; DCA, deoxycholic acid; DMH, 1,2-dimethylhydrazine; FAP, familial adenomatous polyposis; GST, glutathione S-transferase; HCA, heterocyclic amines; IARC, International Agency for Research on Cancer; HFA, human flora associated; IQ, 2-amino-3-methylimidazo[4,5$f$ lquinoline; LCA, lithocholic acid; MAM, methylazoxymethanol; MNNG, $N$-methyl- $N$-nitro- $N$-nitroguanidine; MSI, microsatellite instability; NOC, $N$-nitroso compounds; O6-med-G, O(6)-methyldeoxyguanosine; PKC, protein kinase C; SCFA, short-chain fatty acids; WCRF, World Cancer Research Fund.

*Corresponding author: Dr C. I. R. Gill, fax +44 2870 324965, email C.Gill@ulst.ac.uk 
not be judged due to limited and contradictory data. Data from prospective studies are less convincing than casecontrol studies (Bingham, 2000). High fibre diets were reported to possibly decrease the risk of CRC, with suggested protective mechanisms including toxin dilution or adsorption (WCRF, 1997; American Gastroenterological Association, 2000). Additionally several micronutrients including carotenoids, ascorbate and folate have been examined epidemiologically in relation to the protective effect associated with vegetables, but the results have frequently been discordant, and coupled with the paucity of data, no strong associations can be observed (Giovannucci et al. 1993; Slattery et al. 1997). Collectively, studies examining the effect of meat consumption (especially red and processed meats) on CRC have produced neither strong nor consistent findings, but it is believed that the weight of evidence points towards a slighty elevated risk (WCRF, 1997; Norat \& Riboli, 2001), although the mechanisms remain unclear. A high intake of saturated or animal fat is possibly related to increased risk (Potter, 1999; Zock, 2001) and does not appear to contribute to the risk associated with meat consumption (Giovannucci \& Goldin, 1997).

High calcium intake has been suggested to offer a protective effect from fat-induced promotion of carcinogenesis by binding cytotoxic bile and fatty acids (Kleibeuker et al. $1996 a$ ) or reducing proliferation in the upper part of the colonic crypt (Bostick et al. 1995). Although most evidence suggests a reduced risk or no association, the results of both cohort and case studies are inconsistent (Potter et al. 1993). Alcohol has long been suspected as a risk factor for colorectal neoplasms, since Stocks first reported a slightly elevated risk in beer drinkers compared to abstainers (Stocks, 1957). Further studies on the topic have provided controversial results as detailed in a review by Potter $e t$ al. (1993). The WCRF reported that elevated alcohol consumption probably increases the risk of cancers of the colon and rectum and that this association is related to total ethanol intake rather than the type of alcoholic drink (WCRF, 1997).

Despite the weight of the epidemiological evidence for diet playing an important role in CRC risk, definitive evidence for causal association is lacking due to difficulties of conducting dietary intervention studies. Surrogate endpoints (biomarkers) are therefore required. Before considering biomarkers that can be used it is necessary to provide a brief summary of the processes of carcinogenesis in the colon.

\section{Colon carcinogenesis}

Approximately $70 \%$ of colorectal malignancies appear to be localised in the left (descending) large bowel between the lower rectum and the splenic fissure, though curiously this subsite distribution appears to be undergoing a proximal shift towards the right (ascending) large bowel, for reasons unknown (Faivre et al. 1989; Ponz de Leon \& Roncucci, 2000). Colonic microarchitecture is characterised by crypts, which are approximately fifty cells in depth. The normal structure and replicative dynamics of the crypts ensure that both stem cells and immediate daughter cells replicate in the lowest region. When the immediate daughter cells divide and migrate they give rise to all the cells that line the crypt. Eventually these cells will reach the surface by which stage they are fully differentiated columnar epithelial cells, covered with microvilli, intimately connected via numerous tight junctions and involved in water and electrolyte transport. The constant outward movement of cells from the crypts should ensure that no interaction occurs between replicating cells and the luminal environment, as such, any mutagens should then only affect the already differentiated colonocytes and effectively have no impact upon the integrity of the crypt cell population (Potter, 1999).

The nature of the microarchitecture was used by Potter to argue that the first mutagenic event occurring to a progenitor cell would have to be a blood-borne rather than a luminal agent. It was suggested that for luminal constituents to have any role in carcinogenesis a polyp must already exist and be in contact with the faecal stream. Other authors offer the contention that a luminal agent could provide the 'first hit' (mutation), if a focal failure in the epithelial barrier occurred due to chemical/physical insult or as a result of failure in terminal differentiation. An agent could then directly or indirectly affect cells in the crypt and lead to the formation of a polyp (Bruce et al. 2000). Mutation of the adenomatous polyposis coli (APC) gene permits an adenomatous polyp to develop and such a formation is considered an important predisposing risk factor for CRC. However, this does not mean that all polyps become malignancies (only approximately $5 \%$ do) nor does it prohibit the possibility that de novo colorectal tumourigenesis may occur (Owen, 1996). The adenomas are well demarcated clumps of epithelial dysplasia, classified into three histological types (tubular, villous and tubulovillous), which increase in prevalence with age, being present in $24-40 \%$ of people over 50 years old (Ponz de Leon \& Roncucci, 2000).

It is estimated that up to $15 \%$ of all CRC are due to genetic predisposition, with a further $60 \%$ due to sporadic CRC that appear to develop from adenomatous polyps. Adenomas and carcinomas develop through a stepwise accumulation of somatic mutations (Fig. 1). Although the precise sequence of genetic events is not completely understood, it involves inactivation of various tumour-suppressing genes (e.g. APC, p53), activation mutations in proto-oncogenes (e.g. k-ras, c-myc) and loss of function in DNA repair genes (e.g. hMLH1, hMSH2). This classic multistep model has been termed the 'adenoma-carcinoma sequence' (Vogelstein et al. 1988; Fearon \& Vogelstein, 1990). For detailed information on the genetic events and pathways to CRC the reader is referred to Potter (1999), Chung (2000), Ponz de Leon \& Percesepe (2000) and Souza (2001).

The potential role of luminal factors in the development of colonic tumours has led to the theory that the large bacterial population in the colon is involved in the formation of carcinogens, tumour promotors and anticarcinogens in the gut (Hill, 1975). This in turn has encouraged the search for dietary components that modulate the gut microflora and its activities and thus may influence CRC, e.g. probiotics, prebiotics and fibre (Table 1). 


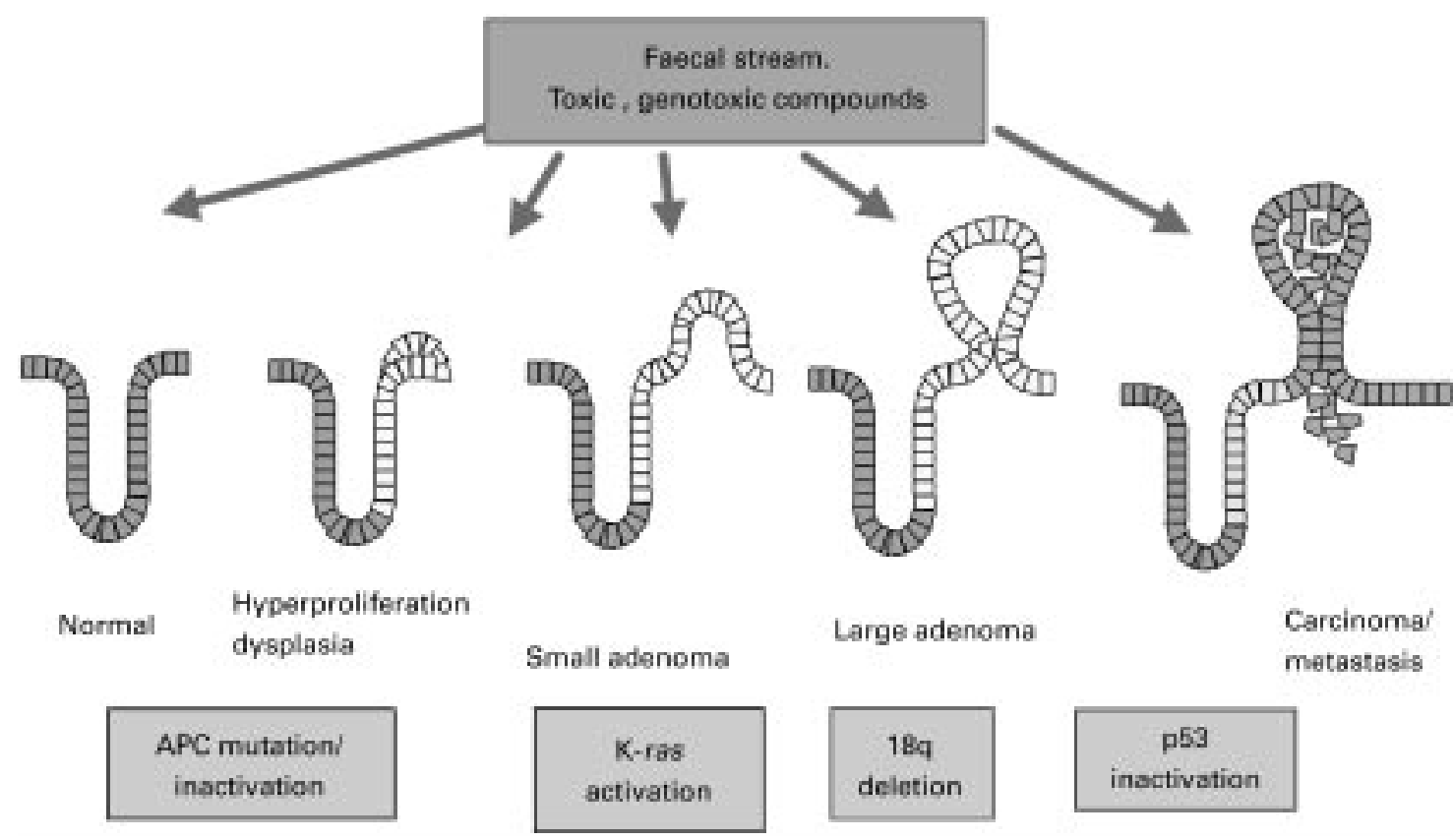

Fig. 1. The adenoma-carcinoma sequence. Inactivation of the adenomatous polyposis coli (APC) gene facilitates the development of a hyperplastic epithelium. Activation of oncogenic ras occurs in early adenomas. Deletion of $18 \mathrm{q}$ is found in dyplastic late adenomas. Finally with the inactivation of p53 colorectal cancer develops. Components of the faecal stream are believed to modulate colorectal carcinogenesis.

\section{Biomarkers for colorectal cancer}

To establish causal relationships between diet and CRC risk and to identify more precisely the dietary components involved, human intervention trials are required. The problem with human intervention studies is that cancer is an impractical endpoint in terms of numbers, cost, study duration and ethical considerations. The long lag phase (up to 20 years) between exposure to a carcinogenic event and appearance of tumours is a particular problem. An alternative strategy is the use of intermediate endpoint biomarkers of cancer, which may be biochemical, molecular, cellular or rooted in pathologic change (e.g. recurrence of polyps, faecal water, epithelial markers).

Biomarkers have been developed from an understanding of the sequence of events leading to colonic cancer, the biology of normal mucosa and the factors associated with changes symptomatic of progression toward cancer and the manifestation of cancer itself. The particular advantages of biomarkers are that they represent short-/intermediate-term endpoints, which allow intervention on a reasonable time scale. Ethical approval is readily obtainable for biomarker studies as they are minimally invasive, with measurements occurring on accessible material (e.g. faeces and small biopsies, FAP). Ideally biomarkers should be sensitive, reproducible and rigorously validated, although this is not the case with all biomarkers in the cancer field. Biomarkers should be causally linked, or correlated with cancer and hence of biological significance. Thus validation of a biomarker is critical to its application as a research tool, as an appropriate response from the marker is required when assayed in cancer patients (e.g. familial adenomatous polyposis, FAP) or in healthy individuals on low-risk and high- risk diets for CRC. The biomarkers available for the study of CRC are composed of two main types: (1) tissue, (2) biochemical. Both categories possess distinct advantages.

\section{Tissue biomarkers}

These endpoints are analysed from a tissue biopsy and as such necessitate invasive procedures of varying complexities to retrieve samples of rectal/colonic mucosa. Use of biopsies increases the technical complexity of studies, but reduces the degree of inference required to interpret the results when compared to biochemical markers. Tissue can be directly observed, manipulated and analysed. Tissue biomarkers, therefore, provide the scope to examine a range of cellular aspects intimately linked to CRC.

\section{Adenoma growth and recurrence}

Adenomas (or polyps) are considered to represent the most likely precursor lesions for colonic cancer in humans. Surveillance and removal generally offer a protective effect, although adenoma recurrence is common (Wehrmann \& Fruhmorgen, 2000). Polyps appear to be the most reliable premalignant biomarkers for $\mathrm{CRC}$, but consequently studies are long (1-5 years) and expensive. The adenoma size and the extent of the villous component are major risk factors associated with high grade dysplasia and as such the malignancy potential of a colorectal polyp increases with size (O'Brien et al. 1990; Simons et al. 1992; Hofstad \& Vatn, 1997). In individuals with a large colon polyp $(>1 \mathrm{~cm})$ the rate of development of CRC is four times faster than expected (Otchy et al. 1996). Larger polyps 
Table 1. Potential anticancer properties of foods/nutrients

\begin{tabular}{|c|c|c|}
\hline Food/nutrient & Potential anticancer activity & References \\
\hline Prebiotics (e.g. inulin, fructo-oligosaccridies) & $\begin{array}{l}\text { Selective effects for Bifidobacterium, Lactobacillus spp. } \\
\text { Fermentation influences bowel function } \\
\text { (e.g. motility) }\end{array}$ & Cummings et al. (2001) \\
\hline Probiotics (e.g. Lactobacillus casei Shirota) & $\begin{array}{l}\text { Beneficially modulate gut physiology (e.g. mucosal } \\
\text { integrity, pH) and microflora content. Increase } \\
\text { carbohydrate fermentation, decrease cytotoxicity }\end{array}$ & $\begin{array}{l}\text { Holzapfel et al. (1998) } \\
\text { Burns \& Rowland }(2000) \\
\text { Hirayama \& Rafter (2000) }\end{array}$ \\
\hline Fermented dairy products & $\begin{array}{l}\text { Increase gut microflora population and carbohydrate } \\
\text { fermentation }\end{array}$ & St-Onge (2000) \\
\hline Fibre and resistant starch & $\begin{array}{l}\text { Increase stool bulk, colonic fermentation and SCFA } \\
\text { synthesis, decrease faecal pH and faecal water } \\
\text { cytotoxicity }\end{array}$ & $\begin{array}{l}\text { Cummings et al. (1996) } \\
\text { Phillips et al. (1995) } \\
\text { Hylla et al. (1998) }\end{array}$ \\
\hline Folate & $\begin{array}{l}\text { Prevents DNA hypomethylation, possible early step } \\
\text { in carcinogenesis }\end{array}$ & Su (2001) \\
\hline Phytoestrogens & $\begin{array}{l}\text { Inhibit proliferation of colon cancer cells, poor } \\
\text { association with risk of CRC }\end{array}$ & $\begin{array}{l}\text { Serraino \& Thompson (1992) } \\
\text { Yanagihara et al. (1993) } \\
\text { Jenab \& Thompson (1996) }\end{array}$ \\
\hline
\end{tabular}

CRC, colorectal cancer; SCFA, short-chain fatty acids.

therefore tend to be more predictive of CRC than small polyps. Dietary effects on cancer risk are assessed through examination of small adenoma recurrence or growth of large polyps. The study groups usually consist of patients with sporadic polyps. Intervention studies completed on such groups have provided conflicting information as to the protective effects of low fat, high fibre and high calcium intakes. Several studies have indicated no effect on recurrence or polyp growth rates (McKeown-Eyssen et al. 1994; Hofstad et al. 1998; Schatzkin et al. 2000), whilst others have indicated an inhibitory effect (MacLennan et al. 1995; Baron et al. 1999). Further polyp studies are currently being undertaken which may resolve these issues including the Concerted Action Polyp Prevention trial and UK Colonic Adenoma Prevention trial. Although polyps are considered a reliable biomarker, the studies can be complex, invasive and time consuming. Simpler, less invasive biomarkers that can be used on healthy subjects are therefore desirable.

\section{Mucosal proliferation}

Colon cancer arises out of perturbation of the normally ordered and balanced proliferation and deletion mechanisms of the cell crypt. This results in hyperproliferation and a shift in the proliferation zone from a restricted band to the entire crypt (Wilson et al. 1990). Generally increased cell proliferation results in an increased tumour load, with carcinogens (e.g. azoxymethane) in animal models often inducing cell proliferation. Patients with a high risk of CRC (e.g. FAP) have a correspondingly high mucosal cell proliferation (Bostick et al. 1997). To determine the extent of mucosal proliferation, tissue biopsy specimens are examined using immunolabelling techniques including proliferating cell nucleus antigen and bromodeoxyuridine or by isolation of individual crypts and determination of mitotic cells (Goodlad et al. 1983). Such studies have provided conflicting data on the effect of high calcium and fibre intakes on hyperproliferation. (Van Munster et al. 1994; Alberts et al. 1997; Macrae et al. 1997; Holt et al. 1998). Although whole crypt microdissection and mitosis counting has been shown to be a reliable, reproducible and robust technique for assessing crypt cell proliferative state (CCPS) in the human colon, the precise relation of an increased CCPS to the neoplastic process remains uncertain (Mills et al. 2001). Furthermore for some methods, noticeable assay variability exists, which may ultimately compromise their usefulness as biomarkers (McShane et al. 1998; Kulldorff et al. 2000). Thus at present, reliance solely on cell proliferation as a marker of diet-related CRC risk would be incautious. The use of mucosal proliferation as a biomarker can be strengthened with the incorporation of apoptosis and differentiation indicators (e.g. in situ terminal transferase nick end labelling, Dolichos biflorus agglutinin), so as to provide a more integrated view of crypt function and architecture (Chang et al. 1997). It has been demonstrated that the non-steroidal anti-inflammatory drug mesalazine significantly increases the rate of apoptosis while concurrently decreasing cell proliferation (ReinacherSchick et al. 2000).

\section{DNA adducts}

Exposure to carcinogens and mutagens can occur from the diet, environment or in some instances even from endogenous pathways. The covalent binding of such compounds (or their metabolites) to DNA results in the formation of adducts, which are believed to contribute to initiation and/or progression of carcinogenesis (Schmid et al. 2000). ${ }^{32} \mathrm{P}$-postlabelling is used as a biomarker to examine the exposure of DNA to carcinogens. The presence of numerous DNA adducts in colonic mucosa is associated with increased risk of CRC (Hamada et al. 1994; PfohlLeszkowicz et al. 1995). Polycyclic aromatic hydrocarbons are environmental pollutants (present in cigarette smoke). They have been demonstrated to form stable DNA adducts 
in various tissues including human colon mucosa and may be responsible for tumour initiation (Alexandrov et al. 1996; Melendez-Colon et al. 1999). Alkylating agents result in $\mathrm{O}(6)$-methyldeoxyguanosine (O6-med-G)-DNA adducts which are believed to represent a marker of exposure to $\mathrm{N}$-nitroso compounds (NOC). These adducts are in part suggested to account for the risk associated with red meat consumption. DNA damage induced by NOC has been demonstrated to vary within the large bowel, being highest in areas with high incidences of bowel tumours (Povey et al. 2000). Most O6-med-GDNA adducts have been found in the proliferating zone of colonic crypts rather than the differentiated cell compartment (Hong et al. 1999). Whilst DNA adducts appear an excellent choice of biomarker for CRC risk, it must be remembered that adduct formation does not always correlate with tumour formation (Alldrick \& Lutz, 1989). DNA in cells isolated from the colon can be rapidly and conveniently collected and damage can be assessed using the COMET assay. Hambly et al. (1997) demonstrated that the DNA damage in colonocytes isolated from rats fed various diets (i.e. low fat, high fat) could be characterised as low or high risk for CRC with the carcinogen (1,2dimethylhydrazine $\mathrm{DMH})$. Studies with lactic acid bacteria have shown that some (not all) can strongly inhibit $(N-$ methyl- $N$-nitro- $N$-nitroguanidine $\mathrm{MNNG}$ ) and DMHinduced gentoxicity in rat colon cells. It was postulated that thiol-containing breakdown products created via catalysis by bacterial proteases could be one mechanism by which MNNG and other carcinogens are deactivated (Pool-Zobel et al. 1996; Wollowski et al. 1999). The cytotoxic and genotoxic effects of numerous known carcinogens were studied in freshly derived human colon tumour cells and in the rodent equivalent, with some disparate results (Pool-Zobel \& Leucht, 1997). Although as yet the technique has not been employed in colon biopsy specimens from human intervention trials, it has been used successfully to demonstrate a protective effect against DNA damage in human lymphocytes for carotenoid-rich foods such as tomato, carrot or spinach. Mechanisms suggested to account for the effect of some vegetables include enhancement of cytosolic (glutathione S-transferase pi GST pi) and DNA repair proteins (Pool-Zobel et al. 1997, 1998).

\section{DNA repair}

Colon mucosal cells are under constant, but low, genotoxic stress. Such damage is normally repaired, but any factors influencing the integrity of the repair process are important in determining the risk of cancer. DNA mismatch repair genes, if inactivated, tend to result in the colorectal mucosal cells accumulating additional mutations at a higher rate, potentially enhancing their capacity for malignant transformation (Boland, 1996). The inactivation of this critical system results in genomic instability, which is particularly evident at microsatellite loci. These are highly repetitive sequences scattered throughout the human genome, most commonly CA, GT, A, T sequences. Currently a panel of five marker genes exists to determine the degree of microsatellite instability (MSI). Tumours can be characterised as high frequency (MSI-H) if two or more markers show instability or low frequency (MSI-L) if only one marker is affected (Boland et al. 1998). The majority of hereditary non-polyposis CRC malignancies show MSI, as do approximately $10-15 \%$ of all sporadic colorectal tumours. Therefore the presence of MSI indicates a failure in the DNA repair mechanisms and an increased susceptibility to genotoxic dietary agents, thus elevating the risk of CRC. No dietary intervention studies have yet been performed with this endpoint.

\section{Oncogene and tumour-suppressor gene mutation}

Mutations in specific oncogenes and tumour-suppressor genes (e.g. K-ras, p53) are involved in tumour development in the colon, as they occur at high frequencies in human colon cancers (Erdman et al. 1997). The expression levels of these genes can be measured and used to demonstrate the effect of various dietary components on tumour formation in colonic mucosa. Addition of the probiotic Bifidobacterium longum to the diet of rats was shown to exert a strong antitumour activity on colonic mucosa by reducing the expression level of ras-p21 expression and cell proliferation. (Singh et al. 1997b; Reddy, 1998). Similarly, a diet high in fish oil ( $n-3$ fatty acids) has also been demonstrated to decrease expression of ras-p21 in colonic mucosa, whilst a diet high in corn oil ( $n-6$ fatty acids) appears to promote tumourigenesis as it increased the expression of this gene (Singh et al. 1997a). Chronic use of sennoside laxatives increases the risk of CRC in rats; a dose of highly purified senna extract has been demonstrated to increase cell proliferation rates in colonic mucosa, although expression of ras-p53 was unaffected (Van Gorkom et al. 2000).

In conclusion, the use of novel tissue biomarkers (genotoxicity, DNA repair capacity, oncogene mutations) offer great potential as judged by numerous animal studies and some limited human data, but they are yet to be exploited widely for dietary intervention trials with colonic biopsies.

\section{Biochemical markers}

In contrast to the invasive techniques needed to obtain colonic tissue, the majority of biochemical markers available can be readily measured in blood, urine or faeces, and thus are minimally or non invasive. Biochemical markers are composed of two main groups, mammalian enzymes and gut microflora associated biomarkers. The former are measures of specific endogenous enzyme activity in blood, urine or biopsy specimens, e.g. CYP1A2, GST, whilst the latter include bacterial enzyme activities and faecal metabolites.

\section{Mammalian enzyme biomarkers}

A common biomarker is the hepatic enzyme CYP1A2, a member of the cytochrome P450 superfamily. It is involved in the metabolic activation of several carcinogens including aromatic and heterocyclic amines. Wide interindividual variation has been described in CYP1A2 activity and this variation may relate to susceptibility to cancer. 
Individuals with high CYP1A2 activity are suggested to have an increased risk of CRC (Lang et al. 1994). Induction of CYP1A2 activity has been reported as a consequence of several factors including diet (reviewed Landi et al. 1999). Ingestion of a diet rich in chargrilled meat has been shown to induce CYP1A2 activity (Fontana et al. 1999), while associations have also been described between cooked food, increased CYP1A2 activity and increased CRC risk (Lang et al. 1994; Badawi et al. 1996). Vegetables appear to have a diverse affect on CYP1A2 with brassica (cruciferous) vegetables increasing and apiaceous (carrot and parsley-like) vegetables reducing activity levels (Lampe et al. 2000b). These effects may in part be the result of the presence or absence of various chemopreventive flavonoids, which are suggested to inhibit activity of CYP isoforms (Sousa \& Marletta, 1985; Bear \& Teel, 2000; Shih et al. 2000).

GST (alpha, pi, mu) are an important family of phase II detoxification enzymes, which play a crucial role in protecting the colon mucosa from dietary carcinogens. Reduction in GST activity is associated with an increased risk for CRC (Szarka et al. 1995). Dietary components have been demonstrated to modulate GST activity in the intestine of rats (O'Neill et al. 1997) and man (Nijhoff et al. 1995). Interestingly, consumption of Brussels sprouts was found to increase GST in rectal biopsies and lymphocytes from blood, suggesting that this marker could be used as a less invasive method. Supplementation of the diet with resistant starch elevates GST (pi) levels in the rat colon probably through alteration of the colonic fermentation profile and microflora population (Treptow van Lishaut et al. 1999). Wheat bran and soya also increase GST activity in the rat colon, with the effects attributed to micronutrients or phytochemicals rather than dietary fibre (Appelt \& Reicks, 1997; Helsby et al. 2000). The use of lactulose separately or in conjunction with $B$. longum has been demonstrated to significantly increase GST levels in rat colon (Challa et al. 1997). Apiaceous vegetables (celery, carrot and parsley-like vegetables) appear to decrease human GST activity in specific groups, whereas brassica vegetables have consistently been shown to increase GST activity levels (Nijhoff et al. 1995; Lampe et al. 2000a).

\section{Gut flora-associated biomarkers}

The relationship between diet, gut microflora and CRC is complex and intimate. Substances entering the colon from the ileum and the resident microflora are major determinants of colonic physiology. These, together with the innate biology of the colon, are pertinent to the initiation and promotion of CRC. The concentration of bacteria resident in the colon increases distally with an estimated 300400 different cultivatable species (belonging to 190 genera) resident within a healthy adult colon (Holzapfel et al. 1998). Approximately 100 of these species are present at concentrations around $10^{11} \mathrm{CFU} / \mathrm{g}$. The anaerobes, Bacteroides, Bifidobacterium and Eubacterium spp., represent greater than $99 \%$ of those species present in the colon. Once the microflora is established, the composition shows little qualitative variation over time (Kleibeuker et al. 1996b), although there is considerable evidence that the metabolic activity of the microflora can be modulated by diet especially non-digestible carbohydrates (fibre, oligosaccharides; Rowland et al. 1985; Rowland, 1988). With the capacity for the microflora to modulate colonic conditions, it becomes obvious why analysing their dynamic interaction with the colonic environment and mucosa is of such interest. The microflora has been implicated in the aetiology of CRC in a number of studies (reviewed in Mallett \& Rowland, 1990) and these observations form the theoretical basis for use of gut flora biomarkers (faecal biomarkers). These biomarkers are advantageous as they can be assessed in faeces, which is readily accessible and non-invasive. They are composed of two main categories; those examining the activity of bacterial enzymes or bacterial metabolites and those based on bioassays of faecal water and metabolites. A number have been used to investigate gut bacterial function (Rowland et al. 1991; 1998) and some have potential mechanistic links to CRC aetiology - for example, 2amino-3-methylimidazo[4,5- $f$ ]quinoline (IQ) activation, $\beta$-glucuronidase and ammonia production.

\section{Bacterial enzymes/metabolites}

\section{IQ activation}

Heterocyclic amines (HCA) are formed during cooking of protein-rich foods. Normally, these molecules require activation by the liver to become mutagens and carcinogens capable of producing tumours in various tissues in rodents and non-human primates (Nagao \& Sugimura, 1993). Certain isoflavones potentially offer a protective effect against HCA-induced carcinogenesis, by reducing DNA adduct formation (Agus et al. 2000). The HCA IQ is a compound that can also be activated in the colon by Eubacterium and Clostridium species to its genotoxic derivative 7-hydroxy-IQ (Van Tassell et al. 1990), which is genotoxic to colon cells in a dose responsive manner (IR Rowland, unpublished results). Diet and the human gut flora interact to modulate the activation rates of IQ (Rumney et al. 1993b). A high-risk diet (high fat and sugar, low calcium) increases activation levels relative to low-risk diets (low fat, high starch) in human flora associated (HFA) rats (Hambly et al. 1997). Diets high in animal fat or fibre also elevate activation levels (Rumney et al. 1993a). Transgalactosylated oligosaccharides supplementation has also been shown to decrease IQ activation in HFA rats (Rowland \& Tanaka, 1993).

\section{$\beta$-Glucuronidase}

Many toxic and carcinogenic compounds and also endogenously produced compounds such as steroids are metabolised in the liver and then conjugated (with glucuronic acid) by phase II enzymes before being excreted via the bile into the small intestine. In the colon, the bacterial enzyme activities of $\beta$-glucuronidase can hydrolyse the conjugates, releasing the parent compound or its hepatic metabolite. In the case of carcinogens and mutagens, the activity of $\beta$-glucuronidase in the colon may increase 
the likelihood of tumour induction. The colon carcinogen $\mathrm{DMH}$ is metabolised in the liver and small amounts of the procarcinogenic conjugate of the activated metabolite methylazoxymethanol (MAM) are excreted in the bile. Hydrolysis of the conjugate by colonic bacteria releases MAM into the colon. Germ-free animals treated with DMH or MAM have fewer colon tumours than do conventional animals (Reddy et al. 1974), and the use of a $\beta$-glucuronidase inhibitor administered in conjunction with the carcinogen (azoxymethane) significantly reduces the number of tumours in the rat colon, indicating that microflora-derived $\beta$-glucuronidase has an important role to play in the aetiology of colon cancer (Takada et al. 1982). The activity of $\beta$-glucuronidase is influenced by diet, with highrisk diets consistently shown to increase $\beta$-glucuronidase activity relative to low-risk diets (Eriyamremu \& Adamson, 1995; Reddy et al. 1977). Recently Hambly and colleagues demonstrated a $2 \cdot 5$-fold increase in $\beta$ glucuronidase activity on a high-risk diet (Hambly et al. 1997). Alternatively various types of fibre including coffee fibre, resistant starch and rice bran decrease the activity of $\beta$-glucuronidase in rats, with the extent of the effect apparently dependent on the nature of the fibre (Gestel et al. 1994; Maziere et al. 1998; Rao et al. 1998). In human studies, wheat bran, oat bran and wholemeal rye have been demonstrated to reduce $\beta$-glucuronidase activity (Reddy et al. 1992; Grasten et al. 2000). Inhibitory effects on enzyme activity have also been observed using lemon grass extract, cumin and black pepper (Suaeyun et al. 1997; Nalini et al. 1998). Dietary supplementation with $B$. longum has proved successful in both rats and man, by decreasing $\beta$-glucuronidase activity, suggesting that the probiotic influences the metabolic activity of certain types of intestinal microflora.

\section{Faecal ammonia}

Epidemiological studies indicate a link between a high intake of protein and the incidence of colon cancer. These studies, together with investigations in vitro and in laboratory animals, have led to the hypothesis that colonic ammonia, a toxic substance produced by bacterial catabolism of protein and urea (Clinton, 1992), may be a potential tumour promoter in the colon. Bacteria assimilate nitrogen to create bacterial protein during carbohydrate fermentation. The colonic ammonia concentration at any given moment therefore depends upon the balance between bacterial protein synthesis and amino acid deamination. As such, increasing the protein content of the diet increases the colonic luminal concentration of protein breakdown products. Ammonia exhibits a number of effects that suggest it may be involved in tumour promotion, including increasing colonic epithelial cell proliferation (Ichikawa \& Sakata, 1998), altering morphology and DNA synthesis and reducing the lifespan of cells (Visek, 1978; Lin \& Visek, 1991). More definitively, it has been shown to increase the incidence of colon carcinomas induced by MNNG in rats (Clinton et al. 1988). A low level of ammonia production in the gut is associated with low protein, high fibre diets, which appear to protect against cancer of the colon. Ammonia levels have been shown to be elevated in rats consuming a diet containing high risk factors for CRC (Hambly et al. 1997). Supplementation of the diet with resistant starch decreased ammonia concentration in HFA rats, whilst wholemeal rye had no effect on human colonic ammonia concentration (Silvi et al. 1999; Grasten et al. 2000). Modification of bacterial metabolism was successful using the probiotic B. longum in rats as it significantly decreased caecal ammonia concentration (Rowland et al. 1998). Inulin, a chicory fraction containing $\beta(2-1)$ fructans, also reduces ammonia in the gut, although not always significantly (Rowland et al. 1998; Hughes \& Rowland, 2001). Transgalacto-oligosaccharides, which are completely fermented in the human colon, also have been shown to have no effect on ammonia concentration (Alles et al. 1999).

\section{$\mathrm{N}$-nitroso compounds}

Nitrate, ingested via diet and drinking water, is readily converted by the nitrate reductase activity of the intestinal microflora to its more reactive and toxic reduction product, nitrite. Nitrite reacts with nitrogenous compounds such as amines, amides and methylureas in the body to produce NOC, many of which are highly carcinogenic, DNA-alkylating agents (Hughes et al. 2001). The reaction can occur chemically in the acidic conditions prevalent in the human stomach and can also be catalysed at neutral $\mathrm{pH}$ by gut bacteria. Bacterial N-nitrosation occurs in the large intestine and can be analysed using a method that determines apparent total NOC (ATNC) in the faeces and several biological fluids. Such an approach was used to demonstrate that $\mathrm{N}$-nitrosation in the large intestine of rats is dependent on the presence of gut microflora (Massey et al. 1988). Although the mechanism for bacterial $\mathrm{N}$-nitrosation is still unknown, concentrations of ATNC positively correlate with intestinal transit time and inversely with faecal output (Hughes et al. 2001). In faecal samples from healthy human subjects, ATNC was detected and its excretion related to both dietary nitrate (Rowland et al. 1991) and red meat consumption (Silvester et al. 1997; Hughes, 1999; Hughes et al. 2001). However a similar association was not found for white meat or fish (Cummings et al. 1996). In conjunction with high meat intakes, wheat bran, resistant starch and vegetable consumption had no effect on faecal ATNC excretion or concentration (Cummings et al. 1996; Silvester et al. 1997; Hughes, 1999).

\section{Diacylglycerols}

Protein kinase $\mathrm{C}(\mathrm{PKC})$ activation is a critical step in the stimulation of cell proliferation. The enzyme can be directly activated in vivo by the secondary messenger diacylglycerol (DAG), which is a lipid produced by phospholipase $\mathrm{C}$ catalysed hydrolysis of phosphatidyinositol and polyphosphoinositides. DAG activates PKC by decreasing the enzyme's requirement for calcium ions. The sustained activation of PKC is believed to be a critical event in tumour promotion as it affects regulation of longterm cellular events such as proliferation and differentiation. Evidence supporting this hypothesis is provided 
by phorbol ester tumour promoters which potently activate PKC by a mechanism that appears analogous to that of DAG. Bacterial microflora can also produce DAG using phospholipids and triglycerides from the colonic contents. The bacterial production of DAG can be enhanced by bile acid (Morotomi et al. 1990). Unsaturated fatty acids and bile acids activate PKC and increased cell proliferation in rat colons, either through a direct method or through an action on the cell membrane (Craven \& DeRubertis, 1988). Hence human subjects with grossly increased fat content of the faeces, e.g. jejunoileal bypass patients, have extremely high luminal DAG concentrations and hyperproliferation of the colonic epithelium (Steinbach et al. 1994). For a detailed review of PKC and its implications in cancer the reader is referred to reviews by Blobe et al. (1994) and O’Brian \& Ward (1989).

\section{Fecapentaenes}

These potent and direct-acting mutagens are glycerol ether compounds containing a pentaene moiety with a chain length of twelve or fourteen (fecapentaenes twelve or fourteen). Both types are found in faeces, although the ratio varies considerably (Baptista et al. 1985). Although fecapentaenes occur in faeces of the majority of Western populations, more detailed epidemiological studies have revealed some anomalies. For example, lower fecapentaene levels have been found in faeces from colorectal patients than in controls (Schiffman et al. 1989) and faecal excretion of fecapentaenes is higher in vegetarians, who are at lower risk from colon cancer (de Kok et al. 1992). These and other studies suggest that the more fecapentaene excreted the lower the risk of CRC. This reasoning has a certain logic since fecapentaenes are very potent, directacting mutagens which would be expected to react extremely rapidly with DNA and other macromolecules in the colonic mucosa. Thus increased faecal excretion may reflect lower endogenous exposure to the genotoxin. The gut microflora has been implicated in fecapentaenes synthesis by the demonstration of this process in vitro by faecal suspensions, under anaerobic conditions, and the inhibition of synthesis by antibiotics and heat sterilisation (Wilkins et al. 1980; Hirai et al. 1982). Further work has established that Bacteroides species are the organisms mainly responsible for fecapentaene production (Van Tassell et al. 1982a). Production of mutagens in vitro is stimulated by bile acids (Van Tassell et al. 1982b; Nair et al. 2000) although they are not thought to be precursors. However, in vivo studies have yielded more equivocal results, as some studies have demonstrated mucosal proliferation, DNA damage and tumour-promoting activity (Hinzman et al. 1987; Vaughan et al. 1987; Zarkovic et al. 1993), whilst others have reported no carcinogenic properties (Ward et al. 1988; Weisburger et al. 1990; Shamsuddin et al. 1991).

\section{Secondary bile acids}

The bile acids consist of a number of related amphiphilic acidic steroids. The primary bile acids, chenodeoxycholic acid and cholic acid, are synthesised from cholesterol in the liver (Hofmann, 1984), conjugated with taurine or glycine and released into the bile to solubilise fats and cholesterol for uptake in the small intestine. The primary bile acids are subject to extensive metabolism by the intestinal microflora (MacDonald et al. 1993), predominantly 7- $\alpha$ dehydroxylation, which converts cholic to deoxycholic acid (DCA) and chenodeoxycholic to lithocholic acid (LCA), thereby increasing their hydrophilicity. These secondary bile acids, which comprise over $80 \%$ of the faecal bile acids, are postulated to play an important role in the aetiology of colon cancer by acting as promoters of the tumourigenic process (Nagengast et al. 1995). The capacity of DCA to enhance colon tumour development in the rat colon could be attenuated by all-trans retinoic acid (Narahara et al. 2000). It is also postulated that a high DCA concentration and DCA to LCA ratio may be a risk indicator of CRC (Kamano et al. 1999). However a recent study by de Kok found no significant correlations with either bile acid concentrations or ratios (de Kok et al. 1999). Although there is no definite proof that bile acids are the cause of CRC, there is considerable evidence to indicate that acid steroids, in particular secondary bile acids, can exert a range of biological and metabolic effects. They induce cell necrosis, hyperplasia, metabolic alteration and DNA synthesis in intestinal mucosal cells, enhance the genotoxicity of a number of mutagens in in vitro assays, and exhibit tumour-promoting activity in the colon (reviewed by Rowland et al. 1985; Radley et al. 1996; Chaplin, 1998; Hofmann, 1999). Secondary bile acids can also induce DNA damage in colon cells (Venturi et al. 1997), leading to apoptosis, as DCA-induced DNA damage triggers calcium ion dependent apoptosis, in a manner independent of p53 (Marchetti et al. 1997; Powolny et al. 2001). It has also been suggested that secondary bile acids influence CRC by selecting for apoptosis-resistant cells (Payne et al. 1995) or potentially through bile acid interactions with important secondary messenger signalling systems known to be activated in CRC (arachidonic acid-prostaglandin E2 and PKC; reviewed in Radley et al. 1996). Serum levels of DCA are correlated with increased rates of mucosal proliferation, which is a known factor in CRC causation (Ochsenkuhn et al. 1999). Diet has an obvious and pronounced effect on bile acids as high levels of animal fat and protein increase both secretion and flow (Thompson et al. 1985; Villalon et al. 1992), but by itself diet cannot be considered harmful, unless in the absence of balancing amounts of carbohydrate (Chaplin, 1998). Fibre (ispaghula husk) has been shown to lower faecal levels of LCA and decrease DCA to LCA ratio (Anderson et al. 1988; Chaplin et al. 2000).

\section{Faecal water activity}

There is considerable evidence that colon tumours are a result of gut luminal factors damaging the mucosa. Furthermore, free reactive and soluble factors are more likely to affect the epithelium than substances bound to the insoluble matrix such as fibre. Therefore, an alternative approach to assaying enzymes or metabolites in faeces is to assess toxicological activity of fractions using short-term tests 
for toxicity, genotoxicity and mutagenicity. Usually the aqueous phase of the human faeces (faecal water) is used (Rafter et al. 1987), since this will contain most of the free reactive species. This approach provides a direct estimate of the potential of the faecal sample to damage the colonic mucosa and has been used to provide insights into the possible processes involved in colon cancer including cytotoxicity and genotoxicity. Despite considerable intra- and interindividual variability in faecal water activity, effective experimental protocols can enable detection of dietary modulations of the level of toxic and genotoxic effects (Osswald et al. 2000).

\section{Faecal water cytotoxicity}

Proliferative zone expansion in the colonic crypts and an increased rate of epithelial proliferation are often viewed as an early step in carcinogenesis. Stimulation of proliferative activity in colonic epithelial may in part be mediated by chemical or physical cytotoxic mechanisms, such that epithelial damage induced by these sources would increase cell loss at the epithelial surface. This would result in a compensatory increase in the mitotic activity of the crypts, thus elevating the risk for CRC. Such considerations led to the development of assays to assess cytotoxic activity in faecal water towards colon cells in vitro (Rafter et al. 1987). It is thought that bile acids, especially secondary bile acids, make a major contribution to faecal water cytotoxicity (Rafter et al. 1987). This technique has been used in a number of dietary intervention studies. Dietary calcium has frequently been shown to reduce the cytotoxicity of faecal water presumably by precipitating soluble bile acids (Van der Meer et al. 1991, 1997; Govers et al. 1993; Lapre et al. 1993). Interestingly a recent study showed that a shift from a dairy product rich diet (high fat) to a dairy product free diet showed an increase in cytotoxicity of the faecal water, possibly as a result of decreased calcium (Glinghammar et al. 1997). Conflicting data exist regarding the effect of resistant starch supplementation on human faecal water activity, with outcomes indicating a decrease or no change in faecal water cytotoxicity (Van Munster et al. 1994; Heijnen et al. 1998). High red meat consumption, which is associated with an increased risk of colon cancer, increases the cytotoxicity of faecal water in rats. This effect was independent of the fat and bile acids content of the faecal water and may be related to dietary haem (Sesink et al. 1999, 2000).

\section{Faecal water genotoxicity}

There is now convincing evidence that CRC is induced by a series of mutational events in a number of critical genes (Vogelstein et al. 1988). How these mutations arise and what induces them is still not fully understood, as there are a variety of causes. Dietary factors are believed to have a role in the carcinogenic process, as the potential for components of food (e.g. HCA, wheat bran) or their metabolites to influence genetic damage has been examined with mutagenic assays (Venitt et al. 1986; Knize et al. 1995; Johansson et al. 1998; Sinha et al. 2001). Venturi et al. (1997) pioneered the use of faecal water genotoxicity testing as a means of assessing the ability of the colonic environment to induce DNA damage in epithelial cells. A wide variation in the genotoxicity of faecal water samples obtained from thirty-five healthy subjects was found, ranging from negligible to high activity (Venturi et al. 1997). Furthermore a human intervention study demonstrated that a shift to a dairy product poor diet did not affect faecal water genotoxicity even though the cytotoxicity did increase (Glinghammar et al. 1997). Most recently it was shown that a diet high in fat and meat but low in dietary fibre increased faecal water genotoxicity, which may contribute to an enhanced risk of CRC (Rieger et al. 1999).

\section{Conclusions}

There is no doubt that in the last few decades we have greatly expanded our knowledge about the causes and risk factors associated with CRC. Currently, a wide range of potential biomarkers is available to augment investigations into the activity of specific foods, compounds and metabolites in CRC. Most of these assays still require further validation before they can be used with complete confidence and compromises must be made in terms of study complexity and the strength of the causal information provided. It is apparent, however, that a sound theoretical basis exists for the use of biomarkers in the study of CRC. The validation of a biomarker is critical to its application as a research tool, as an appropriate response from the indicator is required when used in cancer patients (e.g. FAP) or in healthy individuals on low-risk and high-risk diets for CRC.

\section{Acknowledgements}

This review has been carried out with the financial support from the Commission of the European Communities, specific RTD programme 'Quality of Life Management of Living Resources', QLK-2000-00067 'Functional foods, gut microflora and healthy ageing'. It does not necessarily reflect its views and in no way anticipates the Commission's future policy in this area.

\section{References}

Agus C, Ilett KF, Kadlubar FF \& Minchin RF (2000) Characterization of an ATP-dependent pathway of activation for the heterocyclic amine carcinogen $N$-hydroxy-2-amino-3-methylimidazo[4, 5-f]quinoline. Carcinogenesis 21, 1213-1219.

Alberts DS, Einspahr J, Ritenbaugh C, Aickin M, Rees-McGee S, Atwood J, Emerson S, Mason-Liddil N, Bettinger L, Patel J, Bellapravalu S, Ramanujam PS, Phelps J \& Clark L (1997) The effect of wheat bran fiber and calcium supplementation on rectal mucosal proliferation rates in patients with resected adenomatous colorectal polyps. Cancer Epidemiology, Biomarkers and Prevention 6, 161-169.

Alexandrov K, Rojas M, Kadlubar FF, Lang NP \& Bartsch H (1996) Evidence of anti-benzo[a]pyrene diolepoxide-DNA adduct formation in human colon mucosa. Carcinogenesis 17, 2081-2083.

Alldrick AJ \& Lutz WK (1989) Covalent binding of $\left[2-{ }^{14} \mathrm{C}\right] 2-$ 
amino-3,8-dimethylimidazo[4,5- $f$-quinoxaline (MeIQx) to mouse DNA in vivo. Carcinogenesis 10, 1419-1423.

Alles MS, Hartemink R, Meyboom S, Harryvan JL, Van-Laere KM, Nagengast FM \& Hautvast JG (1999) Effect of transgalactooligosaccharides on the composition of the human intestinal microflora and on putative risk markers for colon cancer. American Journal of Clinical Nutrition 69, 980-991.

American Gastroenterologcal Association (2000) AGA Technical review: impact of dietary fiber on colon cancer occurence. Gastroenterology 118, 1235-1257.

Anderson JW, Zettwoch N, Feldman T, Tietyen-Clark J, Oeltgen P \& Bishop CW (1988) Cholesterol-lowering effects of psyllium hydrophilic mucilloid for hypercholesterolemic men. Archives of Internal Medicine 148, 292-296.

Appelt LC \& Reicks MM (1997) Soy feeding induces phase II enzymes in rat tissues. Nutrition and Cancer 28, 270-275.

Badawi AF, Stern SJ, Lang NP \& Kadlubar FF (1996) Cytochrome P-450 and acetyltransferase expression as biomarkers of carcinogen-DNA adduct levels and human cancer susceptibility. Progress in Clinical and Biological Research 395, 109-140.

Baptista J, Bruce WR, Gupta I, Krepinski JJ, Van Tassell RL \& Wilkins TD (1985) On the distribution of fecapentaenes, the fecal mutagens, in the human population. Cancer Letters 22, 299.

Baron JA, Beach M, Mandel JS, van-Stolk RU, Haile RW, Sandler RS, Rothstein R, Summers RW, Snover DC, Beck GJ, Bond JH, Greenberg ER (1999) Calcium supplements for the prevention of colorectal adenomas. Calcium Polyp Prevention Study Group. New England Journal of Medicine 340, 101-107.

Bear WL \& Teel RW (2000) Effects of citrus flavonoids on the mutagenicity of heterocyclic amines and on cytochrome P450 1A2 activity. Anticancer Research 20, 3609-3614.

Bingham SA (2000) Diet and colorectal cancer prevention. Biochemical Society Transactions 28, 12-16.

Blobe GC, Obeid LM \& Hannun YA (1994) Regulation of protein kinase $\mathrm{C}$ and role in cancer biology. Cancer and Metastasis Reviews 13, 411-431.

Boland CR (1996) Roles of the DNA mismatch repair genes in colorectal tumorigenesis. International Journal of Cancer 69, 47-49.

Boland CR, Thibodaeu SN, Hamilton SR, Sidransky D, Eshleman JR, Burt RW, Meltzer SJ, Rodriguez-Bigas MA, Fodde R, Ranzani GN \& Srivastavas S (1998) A National Institute workshop in microsatellite instability for cancer detection and familial predisposition: development of international criteria for the determination of microsatellite instability in colorectal cancer. Cancer Research 58, 5248-5257.

Bostick RM, Fosdick L, Grandits GA, Lillemoe TJ, Wood JR, Grambsch P, Louis TA \& Potter JD (1997) Colorectal epithelial cell proliferative kinetics and risk factors for colon cancer in sporadic adenoma patients. Cancer Epidemiology, Biomarkers and Prevention 6, 1011-1019.

Bostick RM, Fosdick L, Wood JR, Grambsch P, Grandits GA, Lillemoe TJ, Louis TA \& Potter JD (1995) Calcium and colorectal epithelial cell proliferation in sporadic adenoma patients: a randomized, double-blinded, placebo-controlled clinical trial. Journal of the National Cancer Institute 87, $1307-1315$.

Boyle P \& Langman JS (2000) ABC of colorectal cancer - epidemiology. British Medical Journal 321, 805-808.

Bruce WR, Giacca A \& Medline A (2000) Possible mechanisms relating diet and risk of colon cancer. Cancer Epidemiology, Biomarkers and Prevention 9, 1271-1279.

Burns AJ \& Rowland IR (2000) Anti-carcinogenicity of probiotics and prebiotics. Current Issues in Intestinal Microbiology 1, 13-24.
Challa A, Rao DR, Chawan CB \& Shackelford L (1997) Bifidobacterium longum and lactulose suppress azoxymethaneinduced colonic aberrant crypt foci in rats. Carcinogenesis 18, 517-521.

Chang WC, Chapkin RS \& Lupton JR (1997) Predictive value of proliferation, differentiation and apoptosis as intermediate markers for colon tumorigenesis. Carcinogenesis 18, 721-730.

Chaplin MF (1998) Bile acids, fibre and colon cancer: the story unfolds. Journal of the Royal Society of Health 118, 53-61.

Chaplin MF, Chaudhury S, Dettmar PW, Sykes J, Shaw AD \& Davies GJ (2000) Effect of ispaghula husk on the faecal output of bile acids in healthy volunteers. Journal of Steroid Biochemistry and Molecular Biology 72, 283-292.

Chung DC (2000) The genetic basis of colorectal cancer: insights into critical pathways of tumorigenesis. Gastroenterology $\mathbf{1 1 9}$, $854-865$.

Clinton SK (1992) Dietary protein and carcinogenesis. In Nutrition, Toxicity, and Cancer, pp. 455-475 [I Rowland, editor]. Boca Raton, FL: CRC Press.

Clinton SK, Bostwick DG, Olson LM, Mangian HJ \& Visek WJ (1988) Effects of ammonium acetate and sodium cholate on $\mathrm{N}$ methyl- $N^{\prime}$-nitro- $N$-nitrosoguanidine-induced colon carcinogenesis of rats. Cancer Research 48, 3035-3039.

Craven PA \& DeRubertis FR (1988) Role of activation of protein kinase $\mathrm{C}$ in the stimulation of colonic epithelial proliferation by unsaturated fatty acids. Gastroenterology 95, 676-685.

Cummings JH, Beatty ER, Kingman SM, Bingham SA \& Englyst HN (1996) Digestion and physiological properties of resistant starch in the human large bowel. British Journal of Nutrition 75, 733-747.

Cummings JH, Macfarlane GT \& Englyst HN (2001) Prebiotic digestion and fermentation. American Journal of Clinical Nutrition 73, Suppl., S415-S420.

de Kok T, Van Faassen A, Glinghammar B, Pachen D, Rafter JJ, Baeten C, Engels L \& Kleinjans JCS (1999) Bile acid concentrations, cytotoxicity, and $\mathrm{pH}$ of fecal water from patients with colorectal adenomas. Digestive Diseases and Sciences 44, 2218-2225.

de Kok TM, van Faassen A, Bausch-Goldbohm RA, ten-Hoor F \& Kleinjans JC (1992) Fecapentaene excretion and fecal mutagenicity in relation to nutrient intake and fecal parameters in humans on omnivorous and vegetarian diets. Cancer Letters 62, 11-21.

Erdman SH, Wu HD, Hixson LJ, Ahnen DJ \& Gerner EW (1997) Assessment of mutations in Ki-ras and p53 in colon cancers from azoxymethane- and dimethylhydrazine-treated rats. Molecular Carcinogenesis 19, 137-144.

Eriyamremu GE \& Adamson I (1995) Alterations in rat colon feces exposed to an acute level of deoxycholate and fed on a Nigerian-like diet. Nutrition Research 15, 869-880.

Faivre J, Bedenne L, Boutron MC, Milan C, Collonges R \& Arveux P (1989) Epidemiological evidence for distinguishing subsites of colorectal cancer. Journal of Epidemiology and Community Health 43, 356-361.

Fearon ER \& Vogelstein B (1990) A genetic model for colorectal tumorigenesis. Cell 61, 759-767.

Fontana RJ, Lown KS, Paine MF, Fortlage L, Santella RM, Felton JS, Knize MG, Greenberg A \& Watkins PB (1999) Effects of a chargrilled meat diet on expression of CYP3A, CYP1A, and P-glycoprotein levels in healthy volunteers. Gastroenterology 117, 89-98.

Gestel G, Besancon P \& Rouanet JM (1994) Comparative evaluation of the effects of two different forms of dietary fibre (rice bran vs. wheat bran) on rat colonic mucosa and faecal microflora. Annals of Nutrition and Metabolism 38, 249-256.

Giovannucci E \& Goldin B (1997) The role of fat, fatty acids, and total energy intake in the etiology of human colon cancer. American Journal of Clinical Nutrition 66, S1564-S1571. 
Giovannucci E, Stampfer MJ, Colditz GA, Rimm EB, Trichopoulos D, Rosner BA, Speizer FE \& Willett WC (1993) Folate, methionine, and alcohol intake and risk of colorectal adenoma. Journal of the National Cancer Institute 85, 875-884.

Glinghammar B, Venturi M, Rowland IR \& Rafter JJ (1997) Shift from a dairy product-rich to a dairy product-free diet: influence on cytotoxicity and genotoxicity of fecal water - potential risk factors for colon cancer. American Journal of Clinical Nutrition 66, 1277-1282.

Goodlad RA, Al-Mukhtar MY, Ghatei MA, Bloom SR \& Wright NA (1983) Cell proliferation, plasma enteroglucagon and plasma gastrin levels in starved and refed rats. Virchows Archives B, Cell Pathology Including Molecular Pathology 43, 55-62.

Govers MJ, Lapre JA, de Vries HT \& Van-der-Meer R (1993) Dietary soybean protein compared with casein damages colonic epithelium and stimulates colonic epithelial proliferation in rats. Journal of Nutrition 123, 1709-1713.

Grasten SM, Juntunen KS, Poutanen KS, Gylling HK, Miettinen TA \& Mykkanen HM (2000) Rye bread improves bowel function and decreases the concentrations of some compounds that are putative colon cancer risk markers in middle-aged women and men. Journal of Nutrition 130, 2215-2221.

Hamada K, Umemoto A, Kajikawa A, Tanaka M, Seraj MJ, Nakayama M, Kubota A \& Monden Y (1994) Mucosa-specific DNA adducts in human small intestine: a comparison with the colon. Carcinogenesis 15, 2677-2680.

Hambly RJ, Rumney CJ, Fletcher JM, Rijken PJ \& Rowland IR (1997) Effects of high- and low-risk diets on gut microfloraassociated biomarkers of colon cancer in human flora-associated rats. Nutrition and Cancer 27, 250-255.

Heijnen ML, van Amelsvoort JM, Deurenberg P \& Beynen AC (1998) Limited effect of consumption of uncooked (RS2) or retrograded (RS3) resistant starch on putative risk factors for colon cancer in healthy men. American Journal of Clinical Nutrition 67, 322-331.

Helsby NA, Zhu S, Pearson AE, Tingle MD \& Ferguson LR (2000) Antimutagenic effects of wheat bran diet through modification of xenobiotic metabolising enzymes. Mutation Research 454, 77-88.

Hill MJ (1975) The role of colon anaerobes in the metabolism of bile acids and steroids and its relation to colon cancer. Cancer 36, Suppl., 2387-2400.

Hinzman MJ, Novotny C, Ullah A \& Shamsuddin AM (1987) Fecal mutagen fecapentaene-12 damages mammalian colon epithelial DNA. Carcinogenesis 8, 1475-1479.

Hirai N, Kingston DG, Van Tassell RL \& Wilkins TD (1982) Structure elucidation of a potent mutagen from human feces. Journal of the American Chemical Society 104, 6149.

Hirayama K \& Rafter J (2000) The role of probiotic bacteria in cancer prevention. Microbes and Infection 2, 681-686.

Hofmann AF (1984) Chemistry and enterohepatic circulation of bile acids. Hepatology 4, Suppl., S4-S14.

Hofmann AF (1999) The continuing importance of bile acids in liver and intestinal disease. Archives of Internal Medicine 159, 2647-2658.

Hofstad B \& Vatn M (1997) Growth rate of colon polyps and cancer. Gastrointestinal Endoscopy Clinics of North America 7, 345-363.

Hofstad B, Vatn MH, Andersen SN, Owen RW, Larsen S \& Osnes M (1998) The relationship between faecal bile acid profile with or without supplementation with calcium and antioxidants on recurrence and growth of colorectal polyps. European Journal of Cancer Prevention 7, 287-294.

Holt PR, Atillasoy EO, Gilman J, Guss J, Moss SF, Newmark H, Fan K, Yang K \& Lipkin M (1998) Modulation of abnormal colonic epithelial cell proliferation and differentiation by low- fat dairy foods: a randomized controlled trial. Journal of the American Medical Association 280, 1074-1079.

Holzapfel WH, Haberer P, Snel J, Schillinger U \& Huis-in't-Veld JH (1998) Overview of gut flora and probiotics. International Journal of Food Microbiology 41, 85-101.

Hong MY, Chapkin RS, Wild CP, Morris JS, Wang N, Carroll RJ, Turner ND \& Lupton JR (1999) Relationship between DNA adduct levels, repair enzyme, and apoptosis as a function of DNA methylation by azoxymethane. Cell Growth and Differentiation 10, 749-758.

Hughes R (1999) The effects of diet on colonic N-nitrosation and biomarkers of DNA damage. PhD Thesis, University of Cambridge.

Hughes R, Cross AJ, Pollock JR \& Bingham S (2001) Dosedependent effect of dietary meat on endogenous colonic Nnitrosation. Carcinogenesis 22, 199-202.

Hughes R \& Rowland IR (2001) Stimulation of apoptosis by two prebiotic chicory fructans in the rat colon. Carcinogenesis $\mathbf{2 2}$, $43-47$.

Hylla S, Gostner A, Dusel G, Anger H, Bartram HP, Christl SU, Kasper H \& Scheppach W (1998) Effects of resistant starch on the colon in healthy volunteers: possible implications for cancer prevention. American Journal of Clinical Nutrition 67, $136-142$.

Ichikawa H \& Sakata T (1998) Stimulation of epithelial cell proliferation of isolated distal colon of rats by continuous colonic infusion of ammonia or short-chain fatty acids is non-additive. Journal of Nutrition 128, 843-847.

Indian Cancer Society (1985) Cancer Incidence in Greater Bombay, by Religion and Sex 1973-1978. Bombay: The Indian Cancer Society.

International Agency for Research on Cancer (1997) Cancer incidence in five continents. Volume VII. IARC Scientific Publications $\mathbf{i}-\mathbf{x x x i v}, 1-1240$.

International Agency for Research on Cancer (2000) GLOBOCAN 2000: Cancer Incidence, Mortality and Prevalence Worldwide. France: International Agency for Research on Cancer.

Jenab M \& Thompson LU (1996) The influence of flaxseed and lignans on colon carcinogenesis and beta-glucuronidase activity. Carcinogenesis 6, 1343-1348.

Johansen C, Mellemgaard A, Skov T, Kjaergaard J \& Lynge E (1993) Colorectal cancer in Denmark 1943-1988. International Journal of Colorectal Disease 8, 42-47.

Johansson G, Holmen A, Persson L, Hogstedt B, Wassen C, Ottova L \& Gustafsson JA (1998) Long-term effects of a change from a mixed diet to a lacto-vegetarian diet on human urinary and faecal mutagenic activity. Mutagenesis 13, 167-171.

Kamano T, Mikami Y, Kurasawa T, Tsurumaru M, Matsumoto M, Kano M \& Motegi K (1999) Ratio of primary and secondary bile acids in feces: possible marker for colorectal cancer? Diseases of the Colon and Rectum 42, 668-672.

Kemppainen M, Raiha I \& Sourander L (1997) A marked increase in the incidence of colorectal cancer over two decades in southwest Finland. Journal of Clinical Epidemiology 50, $147-151$.

Kleibeuker JH, Mulder NH, Cats A, Van-der-Meer R \& de Vries EG (1996a) Calcium and colorectal epithelial cell proliferation. Gut 39, 774-775.

Kleibeuker JH, Nagengast FM \& Van-der-Meer R (1996b) Carcinogenesis in the colon. In Prevention and Early Detection of Colorectal Cancer, pp. 46-62 [GP Young, P Rozen and B Levin, editors]. London: WB Saunders Company Ltd.

Knize MG, Dolbeare FA, Cunningham PL \& Felton JS (1995) Mutagenic activity and heterocyclic amine content of the human diet. Princess Takamatsu Symposium 23, 30-38.

Kulldorff M, McShane LM, Schatzkin A, Freedman LS, 
Wargovich MJ, Woods C, Purewal M, Burt RW, Lawson M, Mateski DJ, Lanza E, Corle DK, O'Brien B \& Moler J (2000) Measuring cell proliferation in the rectal mucosa. Comparing bromodeoxyuridine (BrdU) and proliferating cell nuclear antigen (PCNA) assays. Journal of Clinical Epidemiology 53, 875-883.

Lampe JW, Chen C, Li S, Prunty J, Grate MT, Meehan DE, Barale KV, Dightman DA, Feng Z \& Potter JD (2000a) Modulation of human glutathione S-transferases by botanically defined vegetable diets. Cancer Epidemiology, Biomarkers and Prevention 9, 787-793.

Lampe JW, King IB, Li S, Grate MT, Barale KV, Chen C, Feng Z $\&$ Potter JD (2000b) Brassica vegetables increase and apiaceous vegetables decrease cytochrome P450 1A2 activity in humans: changes in caffeine metabolite ratios in response to controlled vegetable diets. Carcinogenesis 21, 1157-1162.

Landi MT, Sinha R, Lang NP \& Kadlubar FF (1999) Chapter 16. Human cytochrome P4501A2. IARC Scientific Publications, $173-195$.

Lang NP, Butler MA, Massengill J, Lawson M, Stotts RC, HauerJensen M \& Kadlubar FF (1994) Rapid metabolic phenotypes for acetyltransferase and cytochrome P4501A2 and putative exposure to food-borne heterocyclic amines increase the risk for colorectal cancer or polyps. Cancer Epidemiology, Biomarkers and Prevention 3, 675-682.

Lapre JA, de Vries HT \& Van-der-Meer R (1993) Cytotoxicity of fecal water is dependent on the type of dietary fat and is reduced by supplemental calcium phosphate in rats. Journal of Nutrition 123, 578-585.

Lin HC \& Visek WJ (1991) Colon mucosal cell damage by ammonia in rats. Journal of Nutrition 121, 887-893.

MacDonald IA, Bokkenheuser VD \& Winter J (1993) Degradation of steriods in the human gut. Journal of Lipid Research 24, 675-700.

McKeown-Eyssen GE, Bright See E, Bruce WR, Jazmaji V, Cohen LB, Pappas SC \& Saibil FG (1994) A randomized trial of a low fat high fibre diet in the recurrence of colorectal polyps. Toronto Polyp Prevention Group. Journal of Clinical Epidemiology 47, 525-536.

MacLennan R, Macrae F, Bain C, Battistutta D, Chapuis P, Gratten H, Lambert J, Newland RC, Ngu M \& Russell A (1995) Randomized trial of intake of fat, fiber, and beta carotene to prevent colorectal adenomas. The Australian Polyp Prevention Project. Journal of the National Cancer Institute 87, 1760-1766.

Macrae FA, Kilias D, Selbie L, Abbott M, Sharpe K \& Young GP (1997) Effect of cereal fibre source and processing on rectal epithelial cell proliferation. Gut 41, 239-244.

McShane LM, Kulldorff M, Wargovich MJ, Woods C, Purewal M, Freedman LS, Corle DK, Burt RW, Mateski DJ, Lawson M, Lanza E, O'Brien B, Lake W, Moler J \& Schatzkin A (1998) An evaluation of rectal mucosal proliferation measure variability sources in the polyp prevention trial: can we detect informative differences among individuals' proliferation measures amid the noise? Cancer Epidemiology, Biomarkers and Prevention 7, 605-612.

Mallett AK \& Rowland IR (1990) Bacterial enzymes: their role in the formation of mutagens and carcinogens in the intestine. Digestive Diseases 8, 71-79.

Marchetti MC, Migliorati G, Moraca R, Riccardi C, Nicoletti I, Fabiani R, Mastrandrea V \& Morozzi G (1997) Possible mechanisms involved in apoptosis of colon tumor cell lines induced by deoxycholic acid, short-chain fatty acids, and their mixtures. Nutrition and Cancer 28, 74-80.

Massey RC, Key PE, Mallett AK \& Rowland IR (1988) An investigation of the endogenous formation of apparent total
$\mathrm{N}$-nitroso compounds in conventional microflora and germ free rats. Food Chemistry and Toxicology 26, 595-600.

Maziere S, Meflah K, Tavan E, Champ M, Narbonne JF \& Cassand P (1998) Effect of resistant starch and/or fat-soluble vitamins $\mathrm{A}$ and $\mathrm{E}$ on the initiation stage of aberrant crypts in rat colon. Nutrition and Cancer 31, 168-177.

Melendez-Colon VJ, Luch A, Seidel A \& Baird WM (1999) Cancer initiation by polycyclic aromatic hydrocarbons results from formation of stable DNA adducts rather than apurinic sites. Carcinogenesis 20, 1885-1891.

Mills SJ, Mathers JC, Chapman PD, Burn J \& Gunn A (2001) Colonic crypt cell proliferation state assessed by whole crypt microdissection in sporadic neoplasia and familial adenomatous polyposis. Gut $\mathbf{4 8}, 41-46$.

Morotomi M, Guillem JG, LoGerfo P \& Weinstein IB (1990) Production of diacylglycerol, an activator of protein kinase $\mathrm{C}$, by human intestinal microflora. Cancer Research 50, 3595-3599.

Nagao M \& Sugimura T (1993) Carcinogenic factors in food with relevance to colon cancer development. Mutation Research 290, 43-51.

Nagengast FM, Grubben MJAL \& van Munster IP (1995) Role of bile acids in colorectal carcinogenesis. European Journal of Cancer 31a, 1067-1070.

Nair PP, Davis KE, Shami S \& Lagerholm S (2000) The induction of SOS function in Escherichia coli K-12/PQ37 by 4-nitroquinoline oxide (4-NQO) and fecapentaenes-12 and -14 is bile salt sensitive: implications for colon carcinogenesis. Mutation Research 447, 179-185.

Nalini N, Sabitha K, Viswanathan P \& Menon VP (1998) Influence of spices on the bacterial (enzyme) activity in experimental colon cancer. Journal of Ethnopharmacology 62, $15-24$.

Narahara H, Tatsuta M, Iishi H, Baba M, Uedo N, Sakai N, Yano $\mathrm{H} \&$ Ishiguro S (2000) K-ras point mutation is associated with enhancement by deoxycholic acid of colon carcinogenesis induced by azoxymethane, but not with its attenuation by alltrans-retinoic acid. International Journal of Cancer 88, 157-161.

Nijhoff WA, Grubben MJ, Nagengast FM, Jansen JB, Verhagen H, van Poppel G \& Peters WH (1995) Effects of consumption of Brussels sprouts on intestinal and lymphocytic glutathione S-transferases in humans. Carcinogenesis 16, 2125-2128.

Norat T \& Riboli E (2001) Meat consumption and colorectal cancer: a review of epidemiologic evidence. Nutrition Reviews 59, 37-47.

O'Brian CA \& Ward NE (1989) Biology of the protein kinase C family. Cancer and Metastasis Reviews 8, 199-214.

O'Brien MJ, Winawer SJ, Zauber AG, Gottlieb LS, Sternberg SS, Diaz B, Dickersin GR, Ewing S, Geller S \& Kasimian D (1990) The National Polyp Study. Patient and polyp characteristics associated with high-grade dysplasia in colorectal adenomas. Gastroenterology 98, 371-379.

Ochsenkuhn T, Bayerdorffer E, Meining A, Schinkel M, Thiede C, Nussler V, Sackmann M, Hatz R, Neubauer A \& Paumgartner G (1999) Colonic mucosal proliferation is related to serum deoxycholic acid levels. Cancer 85, 1664-1669.

O’Neill IK, Loktionov A, Manson MM, Ball H, Bandaletova T \& Bingham SA (1997) Comparison of metabolic effects of vegetables and teas with colorectal proliferation and with tumour development in DMH-treated F344 rats. Cancer Letters 114, 287-291.

Osswald K, Becker TW, Grimm M, Jahreis G \& Pool-Zobel BL (2000) Inter- and intra-individual variation of faecal water genotoxicity in human colon cells. Mutation Research 472, 59-70.

Otchy DP, Ransohoff DF, Wolff BG, Weaver A, Ilstrup D, Carlson H \& Rademacher D (1996) Metachronous colon 
cancer in persons who have had a large adenomatous polyp. American Journal of Gastroenterology 91, 448-454.

Owen DA (1996) Flat adenoma, flat carcinoma, and de novo carcinoma of the colon. Cancer 77, 3-6.

Payne CM, Bernstein H, Bernstein C \& Garewal H (1995) Role of apoptosis in biology and pathology: resistance to apoptosis in colon carcinogenesis. Ultrastructural Pathology 19, 221-248.

Pfohl-Leszkowicz A, Grosse Y, Carriere V, Cugnenc PH, Berger A, Carnot F, Beaune P \& de-Waziers I (1995) High levels of DNA adducts in human colon are associated with colorectal cancer. Cancer Research 55, 5611-5616.

Phillips J, Muir JG, Birkett A, Lu ZX, Jones GP, O’Dea K \& Young GP (1995) Effect of resistant starch on fecal bulk and fermentation-dependent events in humans. American Journal of Clinical Nutrition 62, 121-130.

Ponz de Leon M \& Percesepe A (2000) Pathogenesis of colorectal cancer. Digestive and Liver Disease 32, 807-821.

Ponz de Leon M \& Roncucci L (2000) The cause of colorectal cancer. Digestive and Liver Disease 32, 426-439.

Pool-Zobel BL, Bub A, Liegibel UM, Treptow-van-Lishaut S \& Rechkemmer G (1998) Mechanisms by which vegetable consumption reduces genetic damage in humans. Cancer Epidemiology, Biomarkers and Prevention 7, 891-899.

Pool-Zobel BL, Bub A, Muller H, Wollowski I \& Rechkemmer G (1997) Consumption of vegetables reduces genetic damage in humans: first results of a human intervention trial with carotenoid-rich foods. Carcinogenesis 18, 1847-1850.

Pool-Zobel BL \& Leucht U (1997) Induction of DNA damage by risk factors of colon cancer in human colon cells derived from biopsies. Mutation Research 375, 105-115.

Pool-Zobel BL, Neudecker C, Domizlaff I, Ji S, Schillinger U, Rumney C, Moretti M, Vilarini I, Scassellati-Sforzolini R \& Rowland I (1996) Lactobacillus- and bifidobacterium-mediated antigenotoxicity in the colon of rats. Nutrition and Cancer 26, $365-380$.

Potter JD (1999) Colorectal cancer: molecules and populations. Journal of the National Cancer Institute 91, 916-932.

Potter JD, Slattery ML, Bostick RM \& Gapstur SM (1993) Colon cancer: a review of the epidemiology. Epidemiologic Reviews 15, 499-545.

Povey AC, Hall CN, Badawi AF, Cooper DP \& O'Connor PJ (2000) Elevated levels of the pro-carcinogenic adduct, $\mathrm{O}(6)-$ methylguanine, in normal DNA from the cancer prone regions of the large bowel. Gut 47, 362-365.

Powolny A, Xu J \& Loo G (2001) Deoxycholate induces DNA damage and apoptosis in human colon epithelial cells expressing either mutant or wild-type p53. International Journal of Biochemistry and Cell Biology 33, 193-203.

Radley S, Pongracz J, Lord J \& Neoptolemos JP (1996) Bile acids and colorectal cancer. Cancer Topics 10, 2-7.

Rafter JJ, Child P, Anderson AM, Alder R, Eng V \& Bruce WR (1987) Cellular toxicity of fecal water depends on diet. American Journal of Clinical Nutrition 45, 559-563.

Rao CV, Chou D, Simi B, Ku H \& Reddy BS (1998) Prevention of colonic aberrant crypt foci and modulation of large bowel microbial activity by dietary coffee fiber, inulin and pectin. Carcinogenesis 19, 1815-1819.

Reddy BS (1998) Prevention of colon cancer by pre- and probiotics: evidence from laboratory studies. British Journal of Nutrition 80, S219-S223.

Reddy BS, Engle A, Simi B \& Goldman M (1992) Effect of dietary fiber on colonic bacterial enzymes and bile acids in relation to colon cancer. Gastroenterology 102, 1475-1482.

Reddy BS, Mangat S, Weisburger JH \& Wynder EL (1977) Effect of high-risk diets for colon carcinogenesis on intestinal mucosal and bacterial beta-glucuronidase activity in F344 rats. Cancer Research 37, 3533-3536.
Reddy BS, Weisburger JH \& Wynder EL (1974) Fecal bacterial beta-glucuronidase: control by diet. Science 183, 416-417.

Reinacher-Schick A, Seidensticker F, Petrasch S, Reiser M, Philippou S, Theegarten D, Freitag G \& Schmiegel W (2000) Mesalazine changes apoptosis and proliferation in normal mucosa of patients with sporadic polyps of the large bowel. Endoscopy 32, 245-254.

Rieger MA, Parlesak A, Pool-Zobel BL, Rechkemmer G \& Bode C (1999) A diet high in fat and meat but low in dietary fibre increases the genotoxic potential of 'faecal water'. Carcinogenesis 20, 2311-2316.

Rowland IR (1988) Factors affecting metabolic activity of the intestinal microflora. Drug Metabolism Reviews 19, 243-261.

Rowland IR, Granli T, Bockman OC, Key PE \& Massey RC (1991) Endogenous N-nitrosation in man assessed by measurement of apparent total $N$-nitroso compounds in faeces. Carcinogenesis 12, 1395-1401.

Rowland IR, Mallett AK \& Wise A (1985) The effect of diet on the mammalian gut flora and its metabolic activities. Critical Reviews in Toxicology 16, 31-103.

Rowland IR, Rumney CJ, Coutts JT \& Lievense LC (1998) Effect of Bifidobacterium longum and inulin on gut bacterial metabolism and carcinogen-induced aberrant crypt foci in rats. Carcinogenesis 19, 281-285.

Rowland IR \& Tanaka R (1993) The effects of transgalactosylated oligosaccharides on gut flora metabolism in rats associated with a human faecal microflora. Journal of Applied Bacteriology 74, 667-674.

Rumney CJ, Rowland IR, Coutts TM, Randerath K, Reddy R, Shah AB, Ellul A \& O'Neill IK (1993a) Effects of risk-associated human dietary macrocomponents on processes related to carcinogenesis in human-flora-associated (HFA) rats. Carcinogenesis 14, 79-84.

Rumney CJ, Rowland IR \& O'Neill IK (1993b) Conversion of IQ to 7-OHIQ by gut microflora. Nutrition and Cancer 19, 67-76.

Sant M, Capocaccia R, Verdecchia A, Gatta G, Micheli A, Mariotto A, Hakulinen T \& Berrino F (1995) Comparisons of colon-cancer survival among European countries: The Eurocare Study. International Journal of Cancer 63, 43-48.

Schatzkin A, Lanza E, Corle D, Lance P, Iber F, Caan B, Shike M, Weissfeld J, Burt R, Cooper MR, Kikendall JW \& Cahill J (2000) Lack of effect of a low-fat, high-fiber diet on the recurrence of colorectal adenomas. Polyp Prevention Trial Study Group. New England Journal of Medicine 342, 1149-1155.

Schiffman MH, Van-Tassell RL, Robinson A, Smith L, Daniel J, Hoover RN, Weil R, Rosenthal J, Nair PP \& Schwartz S (1989) Case-control study of colorectal cancer and fecapentaene excretion. Cancer Research 49, 1322-1326.

Schmid K, Nair J, Winde G, Velic I \& Bartsch H (2000) Increased levels of promutagenic etheno-DNA adducts in colonic polyps of FAP patients. International Journal of Cancer 87, 1-4.

Serraino M \& Thompson LU (1992) Flaxseed supplementation and early markers of colon carcinogenesis. Cancer Letters 63, 159-165.

Sesink AL, Termont DS, Kleibeuker JH \& Van-der-Meer R (2000) Red meat and colon cancer: dietary haem, but not fat, has cytotoxic and hyperproliferative effects on rat colonic epithelium. Carcinogenesis 21, 1909-1915.

Sesink ALA, Termont D, Kleibeuker JH \& Van der Meer R (1999) Red meat and colon cancer: the cytotoxic and hyperproliferative effects of dietary heme. Cancer Research 59, 5704-5709.

Shamsuddin AM, Ullah A, Baten A \& Hale E (1991) Stability of fecapentaene-12 and its carcinogenicity in F-344 rats. Carcinogenesis 12, 601-607.

Shih H, Pickwell GV \& Quattrochi LC (2000) Differential effects 
of flavonoid compounds on tumor promoter-induced activation of the human CYP1A2 enhancer. Archives of Biochemistry and Biophysics 373, 287-294.

Silvester KR, Bingham SA, Pollock JRA, Cummings JH \& O'Neill IK (1997) Effect of meat and resistant starch on fecal extraction of apparent $N$-nitroso compounds and ammonia from the human large bowel. Nutrition and Cancer 29, 13-23.

Silvi S, Rumney CJ, Cresci A \& Rowland IR (1999) Resistant starch modifies gut microflora and microbial metabolism in human flora-associated rats inoculated with faeces from Italian and UK donors. Journal of Applied Microbiology 86, 521-530.

Simons BD, Morrison AS, Lev R \& Verhoek-Oftedahl W (1992) Relationship of polyps to cancer of the large intestine. Journal of the National Cancer Institute 84, 962-966.

Singh J, Hamid R \& Reddy BS (1997a) Dietary fat and colon cancer: modulating effect of types and amount of dietary fat on ras-p21 function during promotion and progression stages of colon cancer. Cancer Research 57, 253-258.

Singh J, Rivenson A, Tomita M, Shimamura S, Ishibashi N \& Reddy BS (1997b) Bifidobacterium longum, a lactic acidproducing intestinal bacterium inhibits colon cancer and modulates the intermediate biomarkers of colon carcinogenesis. Carcinogenesis 18, 833-841.

Sinha R, Kulldorff M, Chow WH, Denobile J \& Rothman N (2001) Dietary intake of heterocyclic amines, meat-derived mutagenic activity, and risk of colorectal adenomas. Cancer Epidemiology Biomarkers \& Prevention 10, 559-562.

Slattery ML, Potter JD, Coates A, Ma KN, Berry TD, Duncan DM \& Caan BJ (1997) Plant foods and colon cancer: an assessment of specific foods and their related nutrients (United States). Cancer Causes and Control 8, 575-590.

Sousa RL \& Marletta MA (1985) Inhibition of cytochrome P-450 activity in rat liver microsomes by the naturally occurring flavonoid, quercetin. Archives of Biochemistry and Biophysics 240, 345-357.

Souza RF (2001) Review article: a molecular rationale for the how, when and why of colorectal cancer screening. Alimentary Pharmacology \& Therapeutics 15, 451-462.

Steinbach G, Morotomi M, Nomoto K, Lupton J, Weinstein IB \& Holt PR (1994) Calcium reduces the increased fecal 1,2-sndiacylglycerol content in intestinal bypass patients: a possible mechanism for altering colonic hyperproliferation. Cancer Research 54, 1216-1219.

Stocks P (1957) Cancer incidence in North Wales and Liverpool region in relation to habit and environment. British Imperial Cancer Campaign, 35th Annual report 1, 27.

St-Onge MP (2000) Consumption of fermented and non fermented dairy products: effects on cholesterol concentrations and metabolism. American Journal of Clinical Nutrition 71, 674-681.

$\mathrm{Su}$ L (2001) Nutritional status of folate and colon cancer risk; evidence from NHANES I epidemiologic follow-up study. Annals of Epidemiology 11, 65-72.

Suaeyun R, Kinouchi T, Arimochi H, Vinitketkumnuen U \& Ohnishi Y (1997) Inhibitory effects of lemon grass (Cymbopogon citratus Stapf) on formation of azoxymethane-induced DNA adducts and aberrant crypt foci in the rat colon. Carcinogenesis 18, 949-955.

Szarka CE, Pfeiffer GR, Hum ST, Everley LC, Balshem AM, Moore DF, Litwin S, Goosenberg EB, Frucht H \& Engstrom PF (1995) Glutathione S-transferase activity and glutathione S-transferase mu expression in subjects with risk for colorectal cancer. Cancer Research 55, 2789-2793.

Takada H, Hirooka T, Hiramatsu Y \& Yamamoto M (1982) Effect of beta-glucuronidase inhibitor on azoxymethaneinduced colonic carcinogenesis in rats. Cancer Research 42 , $331-334$.
Thompson MH, Owen RW, Hill MJ \& Cummings JH (1985) Factors affecting faecal bile acid concentrations: effect of fat and fibre. Biochemical Society Transactions 13, 392.

Treptow van Lishaut S, Rechkemmer G, Rowland I, Dolara P \& Pool-Zobel BL (1999) The carbohydrate crystalean and colonic microflora modulate expression of glutathione S-transferase subunits in colon of rats. European Journal of Nutrition 38, $76-83$.

Van der Meer R, Lapre JA, Govers MJ \& Kleibeuker JH (1997) Mechanisms of the intestinal effects of dietary fats and milk products on colon carcinogenesis. Cancer Letters 114, $75-83$.

Van der Meer R, Termont DS \& de Vries HT (1991) Differential effects of calcium ions and calcium phosphate on cytotoxicity of bile acids. American Journal of Physiology 260, G142-G147.

Van Gorkom BA, Karrenbeld A, van der Sluis T, Koudstaal J, de Vries EG \& Kleibeuker JH (2000) Influence of a highly purified senna extract on colonic epithelium. Digestion 61, $113-120$.

Van Munster IP, Tangerman A \& Nagengast FM (1994) Effect of resistant starch on colonic fermentation, bile acid metabolism, and mucosal proliferation. Digestive Diseases and Sciences 39, 834-842.

Van Tassell RL, Kingston DG \& Wilkins TD (1990) Metabolism of dietary genotoxins by the human colonic microflora; the fecapentaenes and heterocyclic amines. Mutation Research 238, 209-221.

Van Tassell RL, MacDonald DK \& Wilkins TD (1982a) Production of a fecal mutagen by Bacteroides spp. Infection Immunology 37, 975.

Van Tassell RL, MacDonald DK \& Wilkins TD (1982b) Stimulation of mutagen production in human feces by bile and bile acids. Mutation Research 103, 233-239.

Vaughan DJ, Furrer R, Baptista J \& Krepinsky JJ (1987) The effect of fecapentaenes on nuclear aberrations in murine colonic epithelial cells. Cancer Letters 37, 199-203.

Venitt S, Bosworth D \& Alldrick AJ (1986) Pilot study of the effect of diet on the mutagenicity of human faeces. Mutagenesis 1, 353-358.

Venturi M, Hambly RJ, Glinghammar B, Rafter JJ \& Rowland IR (1997) Genotoxic activity in human faecal water and the role of bile acids: a study using the alkaline comet assay. Carcinogenesis 18, 2353-2359.

Villalon L, Tuchweber B \& Yousef IM (1992) Low protein diets potentiate lithocholic acid-induced cholestasis in rats. Journal of Nutrition 122, 1587-1596.

Visek WJ (1978) Diet and cell growth modulation by ammonia. American Journal of Clinical Nutrition 31, S216-S220.

Vogelstein B, Fearon ER, Hamilton SR, Kern SE, Preisinger AC, Leppert M, Nakamura Y, White R, Smits AM \& Bos JL (1988) Genetic alterations during colorectal-tumor development. New England Journal of Medicine 319, 525-532.

Ward JM, Anjo T, Ohannesian L, Keefer LK, Devor DE, Donovan PJ, Smith GT, Henneman JR, Streeter AJ \& Konishi N (1988) Inactivity of fecapentaene-12 as a rodent carcinogen or tumor initiator. Cancer Letters 42, 49-59.

Wehrmann K \& Fruhmorgen P (2000) Removing adenomas reduces colon carcinoma risk up to $90 \%$. Effective cancer prevention with the endoscope. MMW Fortsch Med 142, 26-29.

Weisburger JH, Jones RC, Wang CX, Backlund JY, Williams GM, Kingston DG, Van-Tassell RL, Keyes RF, Wilkins TD $\&$ de Wit PP (1990) Carcinogenicity tests of fecapentaene-12 in mice and rats. Cancer Letters 49, 89-98.

Wilkins TD, Lederman M, Van Tassell RL, Kingston DG \& Henion J (1980) Characterization of a mutagenic bacterial 
product in human feces. American Journal of Clinical Nutrition 33, 2513-2520.

Wilson RG, Smith AN \& Bird CC (1990) Immunohistochemical detection of abnormal cell proliferation in colonic mucosa of subjects with polyps. Journal of Clinical Pathology 43, $744-747$.

Wollowski I, Ji ST, Bakalinsky AT, Neudecker C \& Pool-Zobel BL (1999) Bacteria used for the production of yogurt inactivate carcinogens and prevent DNA damage in the colon of rats. Journal of Nutrition 129, 77-82.

World Cancer Research Fund (1997) Diet, Nutrition and the Prevention of Cancer: A Global Perspective. Washington, DC:
World Cancer Research Fund/American Institute of Cancer Research.

Yanagihara K, Ito A, Toge T \& Numoto M (1993) Antiproliferative effects of isoflavones on human cancer cell lines established from the gastrointestinal tract. Cancer Research 53, 5815-5821.

Zarkovic M, Qin X, Nakatsuru Y, Oda H, Nakamura T, Shamsuddin AM \& Ishikawa T (1993) Tumor promotion by fecapentaene-12 in a rat colon carcinogenesis model. Carcinogenesis 14, 1261-1264.

Zock PL (2001) Dietary fats and cancer. Current Opinion in Lipidology 12, 5-10. 